ISSN (Print) : 1412-7601

ISSN (Online) : 2654-8712

Volume 4, No.2 September 2018

EKONOBIS

http://www.ekonobis.unram.ac.id

\title{
Model Pemberdayaan UKM Berbasis Potensi Lokal Dalam Rangka Pengentasan Kemiskinan Di Kawasan Pesisir Pantai Cemara Lembar Kabupaten Lombok Barat
}

\author{
Masrun, Akhmad Jufri, Titi Yuniarti. \\ Universitas Mataram
}

\begin{tabular}{lll}
\hline A R T ICLE INF O & Received : 15 Juli 2018; Accepted: 10 Agustus 2018; Published: September 2018 \\
\hline
\end{tabular}

Keywords :

UKM, Poverty Alleviation.

ABSTRACT : The purpose of this study is to form a model of empowerment of SMEs based on local potential to improve the skills of entrepreneurs so they can be motivated to try, be creative and innovative in carrying out their business activities. The research was conducted by field survey method in the coastal area of Cemara Lembar Beach, West Lombok Regency. This activity is to identify opportunities and business feasibility of micro-small entrepreneurs. Furthermore, a model for SME empowerment can be formed in order to solve the problems it faces. From this activity, it is expected that SME entrepreneurs can improve the quality and quantity of their business results so that they will encourage increased income. The results of the study show that of the five businesses analyzed economically it is indeed profitable, but the most feasible / developed for the time being in the coastal area of Pantai Cemara Lembar there are three business sectors, namely shrimp paste farming, shrimp farming and fish trading business. From the model can be formed formed, showing: a). the role of the government in capital assistance other than banking institutions and skills assistance, b). SME entrepreneurs need to form groups / institutions as a forum for SMEs, c). the existence of business partners to assist in the marketing and processing of production.

Kata Kunci :

UKM, Pengentasan

Kemiskinan
ABSTRAK : Tujuan penelitian ini adalah terbentuknya Model pemberdayaan UKM berbasis potensi lokal untuk meningkatkan keterampilan pengusaha agar dapat termotivasi untuk berusaha, kreatif dan inovatif dalam menjalankan kegiatan usahanya. Penelitian dilakukan dengan metode survey lapangan di kawasan pesisir Pantai Cemara Lembar Kabupaten Lombok Barat. Kegiatan ini untuk mengidentifikasi peluang dan kelayakan usaha dari pengusaha kecil mikro. Selanjutnya dapat terbentuknya model pemberdayaan UKM dalam rangka untuk memecahkan masalah yang dihadapinya. Dari kegiatan ini, diharapkan para pengusaha UKM dapat meningkatkan kualitas dan kuantitas hasil usahanya sehingga akan mendorong peningkatan penghasilan. Dari hasil penelitian menunjukkan bahwa dari lima usaha yang dianalisis secara ekonomi memang menguntungkan, namun yang paling layak/unggul dikembangkan untuk sementara di kawasan pesisir Pantai Cemara Lembar ada tiga bidang usaha yaituusaha terasi udang, budidaya tambak udang dan usaha dagang ikan. Dari model dapat terwujud dibentuk, menunjukkan : a). peran pemerintah dalam bantuan modal selain dari lembaga perbankan dan bantuan ketrampilan, b). pengusaha UKM perlu membentuk kelompok/kelembagaan sebagai wadah UKM, c). adanya mitra usaha untuk membantu dalam pemasaran dan pengolahan hasil produksi.

Corresponding Author:

Alamat : Program Studi Ekonomi Pembangunan, Fakultas Ekonomi dan Bisnis, Universitas Mataram, Jln. Majapahit No. 62 Mataram.

e-mail: masrun@unram.ac.id 


\section{PENDAHULUAN}

\section{Latar Belakang}

Pada masa krisis ekonomi yang berkepanjangan, UKM dapat bertahan dan mempunyai potensi untuk berkembang. Dengan demikian UKM dapat dijadikan andalan untuk masa yang akan datang dan harus didukung dengan kebijakan-kebijakan yang kondusif. Disamping itu permasalahanpermasalahan yang menghambat usahausaha pemberdayaan UKM harus dihilangkan. Konstitusi kebijakan ekonomi pemerintah harus menempatkan UKM sebagai prioritas utama dalam pemulihan ekonomi, untuk membuka kesempatan kerja/menyerap tenaga kerja.

Menurut Amirawulandari (2007), dalam pembangunan ekonomi di Indonesia UKM selalu digambarkan sebagai sektor yang mempunyai peranan yang penting, karena sebagian besar jumlah penduduknya berpendidikan rendah dan hidup dalam kegiatan usaha kecil baik disektor tradisional maupun modern. Peranan usaha kecil tersebut menjadi bagian yang diutamakan dalam setiap perencanaan tahapan pembangunan yang dikelola oleh Departemen Perindustrian dan Perdagangan maupun Departemen Koperasi dan UKM, namun usaha pengembangan yang telah dilaksanakan masih belum memuaskan hasilnya.

Kawasan pesisir Pantai Cemara Lembar Kabupaten Lombok Barat memiliki potensi sumber daya wilayah pesisir dan laut yang cukup besar untuk dikelola oleh UKM yang diharapkan mampu mengangkat harkat dan martabat serta kesejahteraan masyarakat pesisir dan laut secara optimal dan berkelanjutan (Achmad E, dkk, 2003) . Namun kenyataan dilapangan menunjukkan bahwa UKM yang ada belum mampu memberikan hasil yang diharapkan, kondisi ini beralasan dikarenakan UKM belum memiliki jiwa kewirausahaan.

Dalam konteks inilah pembinaan wirausaha UKM dapat diterapkan, karena pendekatan ini sebagai solusi dalam menanggulangi permasalahan yang antara lain : tidak mempunyai kemampuan manajerial, etos kerja rendah, tidak memiliki pembukuan usaha yang memadai, pemasaran produk yang lemah, kurang dapat mengendalikan keuangan, kemampuan daya tawar dan negosiasi yang terbatas dan tidak memiliki wawasan bisnis.

Diharapkan pengusaha UKM berwirausaha terampil dengan dapat termotivasi untuk berusaha, kreatif dan inovasi dalam menjalankan kegiatan usahanya. Disamping itu dapat meningkatkan kualitas dan kuantitas hasil usahanya sehingga akan mendatangkan peningkatan pendapatan dan kesejahteraan mereka.

Pengembangan UKM menjadi suatu hal yang krusial mengingat UKM mempunyai peranan yang demikian penting untuk pertumbuhan ekonomi sebuah negara termasuk di negara Indonesia (Tambunan, 2005). UKM di Indonesia telah memberikan kontribusi terhadap penyerapan tenaga kerja sebesar $99,74 \%$ dari total serapan nasional dan menurut laporan BPS (2006) sektor ini secara significant ikut mengatasi pengangguran dan mampu memberikan kontribusi terhadap PDB sebesar Rp 1.013,5 trilyun atau $56,73 \%$. Besarnya kontribusi ini, menunjukkan bahwa UKM mempunyai kemampuan untuk memperkuat perekonomian nasional (Prawirokusuma, 2000). Meskipun secara ekonomi UKM mempunyai kontribusi yang signifikan terhadap pertumbuhan ekonomi, namun dalam pengembangannya menghadapi berbagai permasalahan. Menurut Winarni (2006) dan Situmorang (2008) permasalahan yang dihadapi UKM adalah (a) kurang permodalan, (b) kesulitan dalam pemasaran, (c) struktur organisasi sederhana dengan pembagian kerja yang tidak baku, (d) kualitas manajemen rendah, (e) kebanyakan tidak mempunayai laporan keuangan, (f) SDM terbatas dan kualitasnya rendah, (g) aspek legalitas lemah, (h) rendahnya kualitas teknologi.

Permasalahan ini mengakibatkan lemahnya jaringan usaha, keterbatasan kemampuan penetrasi pasar dan diversifikasi pasar, skala ekonomi terlalu kecil dan lebih jauh lagi UKM tidak memiliki keunggulan kompetitif. Melihat berbagai masalah yang dihadapi dalam pengembangan UKM, maka perlu upaya melalui pembinaan UKM. Sehingga permasalahan yang dihadapi UKM sebaiknya dijadikan input atau bahan 
pertimbangan dalam merumuskan pembinaan, agar dapat berjalan secara efektif dan efisien.

\section{TINJAUAN PUSTAKA}

Krisis yang terjadi di Indonesia sejak tengah tahun 1997 sampai saat ini belum menunjukkan tanda-tanda akan berakhir. Krisis ini juga telah mengakibatkan kedudukan posisi pelaku sektor ekonomi berubah. Usaha besar satu persatu pailit karena bahan baku impor meningkat secara drastis, biaya cicilan utang meningkat sebagai akibat dari nilai tukar rupiah terhadap dolar yang menurun dan berfluktuasi. Sektor perbankan juga ikut terpuruk ikut memperparah sektor industri dari sisi permodalan. Banyak perusahaan yang tidak mampu lagi meneruskan usaha karena tingkat bunga yang tinggi. Berbeda dengan UKM sebagian besar tetap bertahan, bahkan cendrung bertambah. Mengapa demikian?

Alasan-alasan UKM bisa bertahan dan cenderung meningkat jumlahnya pada masa krisis menurut Amirawulandari (2007) adalah :

1. Sebagian besar UKM memproduksi barang konsumsi dan jasa-jasa dengan elastitas permintaan terhadap pendapatan yang rendah, maka tingkat pendapatan rata-rata masyarakat tidak banyak berpengaruh terhadap permintaan barang yang dihasilkan. Sebaliknya kenaikan tingkat pendapatan juga tidak berpengaruh pada permintaan.

2. Sebagian besar UKM tidak mendapat modal dari bank. Implikasinya keterpurukan sektor perbankan dan naiknya suku bunga, tidak banyak mempengaruhi sektor ini. Berbeda dengan sektor perbankan bermasalah, maka UKM ikut terganggu kegiatan usahanya. Sedangkan usaha berkala besar dapat bertahan. Di Indonesia, UKM mempergunakan modal sendiri dari tabungan dan aksesnya terhadap perbankan sangat rendah.

3. UKM mempunyai modal yang terbatas dan pasar yang bersaing, dampaknya UKM mempunyai spesialisasi produksi yang ketat. Hal ini memungkinkan UKM mudah untuk pindah dari usaha yang satu ke usaha lain, hambatan keluar-masuk tidak ada.

4. Reformasi menghapuskan hambatanhambatan di pasar, proteksi industri hulu dihilangkan, UKM mempunyai pilihan lebih banyak dalam pengadaan bahan baku. Akibatnya biaya produksi turun dan efisiensi meningkat. Tetapi karena bersamaan dengan terjadinya krisis ekonomi, maka pengaruhnya tidak terlalu besar.

5. Dengan adanya krisis ekonomi yang berkepanjangan menyebabkan sektor formal banyak memberhentikan pekerjapekerjanya. Para penganggur tersebut memasuki sektor informal, melakukan kegiatan usaha yang umumnya bersekala kecil, akibatnya jumlah UKM meningkat.

Pada masa krisis ekonomi yang berkepanjangan, UKM dapat bertahan dan mempunyai potensi untuk berkembang. Dengan demikian UKM dapat dijadikan andalan untuk masa yang akan datang dan harus didukung dengan kebijakan-kebijakan yang kondusif, serta persoalan-persoalan yang menghambat usaha-usaha pemberdaya an UKM harus dihilangkan. Konstitusi kebijakan ekonomi Pemerintah harus menempatkan UKM sebagai prioritas utama dalam pemulihan ekonomi, untuk membuka kesempatan kerja dan mengurangi jumlah pengangguran.

Bagian dari tulisan ini akan dimulai dengan mengajukan sebuah pertanyaan menarik yakni : bagaimana cara melakukan pembinaan dan pengembangan terhadap UKM dalam konteks pasar bebas dan terbuka? Jika diteliti lebih rinci ternyata UKM itu tidak homogin. Pandangan umum bahwa UKM itu memiliki sifat dan jiwa enterpreneurship (kewiraswastaan) adalah kurang tepat. Ada sub kelompok UKM yang memiliki sifat enterpreneurship tetapi ada pula yang tidak menunjukkan sifat tersebut. Dengan menggunakan kriteria enterpreneurship maka kita dapat membagi UKM dalam empat bagian (Amirawulandari, 2007), yakni:

1) Livelihood Activities : UKM yang masuk kategori ini pada umumnya mencari kesempatan kerja untuk mencari nafkah. Para pelaku dikelompok ini tidak memiliki jiwa enterpreneurship. Kelompok ini 
disebut sebagai sektor informal. Di Indonesia jumlah UKM kategori ini adalah yang terbesaar.

2) Micro enterprise : UKM ini lebih bersifat "Artisan" (pengrajin) dan tidak bersifat enterpreneurship (kewiraswastaan). Jumlah UKM di Indonesia juga relatif besar.

3) Small Dynamic Enterprises : UKM ini yang sering memiliki jiwa enterpreneurship. Banyak pengusaha skala menengah dan besar yang tadinya berasal dari kategori ini. Kalau dibina dengan baik maka sebagian dari UKM kategori ini akan masuk kekategori empat. Jumlah kelompok UKM ini jauh lebih kecil dari jumlah UKM yang masuk kategori satu dan dua. Kelompok UKM ini sudah bisa menerima pekerjaan sub-kontrak dan ekspor.

4) Fast Moving Enterprises : ini adalah UKM tulen yang memiliki jiwa enterpreneurship yang sejati. Dari kelompok ini kemudian akan muncul usaha skala menengah dan besar. Kelompok ini jumlahnya juga lebih sedikit dari UKM kategori satu dan dua.

Dilihat dari pembinaan yang efektif maka sebaiknya pemerintah memusatkan perhatiannya pada UKM kategori satu dan dua. Kelompok ini juga dapat menyerap materi pelatihan. Tujuan pembinaan terhadap UKM katergori ini adalah untuk mengembangkan mereka menjadi usaha sekala menengah. Secara konseptual penulis menganggap ada dua faktor kunci yang bersifat internal yang harus diperhatikan dalam proses pembinaan UKM. Pertama, sumber daya manusia (SDM), kemapuan untuk meningkatkan kualitas SDM baik atas upaya sendiri atau ajakan pihak luar. Selain itu dalam SDM juga penting untuk memperhatikan etos kerja dan mempertajam naluri bisnis. Kedua, manajemen, pengertian manajemen dalam praktek bisnis meliputi tiga aspek yakni berpikir, bertindak dan pengawasan.

Kewirausahaan adalah kegiatan yang dilakukan oleh seseorang untuk menciptakan dan mengejar peluang sesuai dengan situasi dirinya. Dalam hal ini kesuksesan merupakan suatu hal yang dapat dicapai. Kewirausahaan juga diartikan sebagai kegiatan yang dilakukan oleh seseorang untuk memulai dan melakukan usahanya sendiri, mengorganisir dan membangun usaha dengan segala resiko. Mengacu pada pengertian tersebut, ada tiga jenis perilaku dalam kewirausahaan (Sukandarrumidi, 2009), yaitu (1) memulai dan mengerjakan usahanya atas dasar inisiatif sendiri, (2) mengorganisir dan dan membangun usahanya sendiri, (3) keberanian dalam menghadapi ketidak pastian dan resiko. Kewirausahaan umumnya dilakukan oleh seseorang yang mempunyai tenaga, keinginan untuk terlibat dalam petualang inovatif, kemauan untuk menerima tanggung jawab pribadi dalam mewujudkan suatu keinginan dengan cara yang mereka pilih, serta mempunyai keinginan yang tinggi untuk berprestasi. Tidak dapat dipungkiri bahwa kewirausahaan membutuhkan kepribadian unggul yang mencerminkan budi luhur dan sifat yang patut di teladani, diartikan sebagai keberanian, keutamaan serta keperkasaan seseorang dalam memenuhi kebutuhan serta memecahkan permasalahan hidup dengan kekuatan yang ada pada dirinya sendiri. Dengan demikian, kewirausahaan adalah himpunan sifat-sifat pribadi yang mengandung unsur keberanian, keutamaan, keteladanan, dan semangat yang bersumber dari kekuatan diri sendiri. Oleh sebab itu, percaya diri merupakan faktor penting dalam meraih sukses, bahkan merupakan prasarat agar dapat survive dalam menghadapi tantangan dan permasalahan hidup.

Proses transformasi yang sedang berlangsung dewasa ini mungkin, sekali lebih dramatis daripada yang pernah ada sebelumnya karena laju perubahan ternyata lebih cepat daripada yang diduga dan dialami sebelumnya. Perubahan tersebut lebih bersifat eksetentif, sehingga dengan memahami konsep dasar kewirausahaan diharapkan setiap individu dapat mengantisipasi perubahan-perubahan yang diperkirakan akan terjadi. Hafsah (2004), sedikitnya ada lima hal yang dapat menunjukkan arti penting kewirausahaan yang dapat meningkatkan keterampilan, yaitu (1) berpikir kreatif, (2) mengambil keputusan secara lebih cepat dan tepat, (3) kepemimpinan, (4) manajerial, dan (5) hubungan antara manusia. Di samping itu, 
penerapan konsep dasar kewirausahaan juga dapat merubah cara berpikir dan cara pandang yang bersifat konvensional ke arah yang lebih moderat, realistis dan dragmatis, kewirausahaan juga dapat merubah kebiasaan cara kerja yang rutin dan emeohon ke arah kerja yang lebih terprogram, terpadu.

Lebih lanjut menurut Hafsah (2004), secara umum dapat dikatakan bahwa setiap wirausahawan memiliki potensi untuk berprestasi. la senantiasa memiliki motivasi yang kuat untuk maju dan berprestasi. Dalam kondisi dan situasi apapun, manusia yang memiliki jiwa wirausaha mampu menolong dirinya sendiri keluar dari permasalahan hidupnya. Manusia sendiri serta tidak mudah menyerah. Berikut dikemukakan beberapa ciri sikap mental wirausaha :

1. Memiliki moral yang tinggi, setidaktidaknya memiliki enam sifat utama yaitu ; (a) ketaqwaan kepada Tuhan Yang Maha Esa (b) kemerdekaan batin (c) keutamaan (d) kasih sayang terhadap sesama manusia (e) loyalitas hukum (f) keadilan.

2. Memiliki sikap mental wirausaha, antara lain : (a) berkemauan keras (b) berkeyakinan kuat atas kekuatan pribadi, untuk ini diperlukan ; pengenalan diri, kepercayaan pada diri sendiri, pemahaman tujuan dan kebutuhan (c) kejujuran dan tanggung jawab, untuk ini diperlukan ; moral yang tinggi, disiplin diri sendiri, (d) ketahanan fisik dan mental, untuk ini diperlukan; kesehatan jasmani dan rohani, kesabaran dan ketabahan (e) ketekunan dan keuletan untuk bekerja keras (f) pemikiran yang konstruktif dan kreatif.

3. Memiliki kepekaan terhadap lingkungan, antara lain : (a) pengenalan terhadap arti lingkungan, (b) rasa syukur atas segala yang diperoleh dan dimiliki, (c) keinginan yang besar untuk menggali dan mendayagunakan sumber daya yang ada di lingkungan setempat, (d) kepandaian untuk menghargai dan memanfaatkan waktu secara efektif.

4. Memiliki keterampilan teknis dalam berwirausaha, antara lain : (a) ketrampilan berpikir kreatif, (b) keterampilan membaca peluang, (c) keterampilan dalam mengambil keputusan, (d) keterampilan dalam kepemimpinan, (e) keterampilan dalam melakukan negosiasi, (f) keterampilan manajerial, (g) keterampilan dalam menjamin komunikasi dan (h) keterampilan melakukan proses adaptasi terhadap perubahan lingkungan.

Ciri lain dari manusia wirausaha yaitu selalu : (1) bekerja keras, (2) optimis dalam bekerja, (3) berusaha menampilkan cara terbaik dalam bekerja, (4) mempunyai dorongan yang kuat untuk berprestasi, (5) mempunyai kemampuan dalam mengorganisir kegiatan, (6) mengutamakan tanggung jawab, (7) berorientasi pada imbalan dan (8) memperhatikan kualitas (Achmad E, 2011).

\section{METODE PENELITIAN}

Penelitian dilakukan dengan metode survey lapangan di kawasan pesisir Pantai Cemara Lembar Kabupaten Lombok Barat. Kegiatan ini untuk mengidentifikasi peluang dan kelayakan usaha dari pengusaha kecil mikro dan mengidentifikasi mental dan jiwa wirausaha dari pengusaha kecil mikro. Kegiatan ini, diharapkan para pengusaha dapat meningkatkan kualitas dan kuantitas hasil usahanya sehingga akan mendorong peningkatan pendapatan/penghasilannya. Meningkatkan pendapatan pengusaha sasaran melalui peningkatan produksi, kualitas produksi dan harga jual di pasaran.

Kegiatan melalui diskusi Focus Group Dischation (FGD)dengan maksud untuk mengarahkan dan mencari solusi dalam memecahkan persoalan yang dihadapi pengusaha UKM sasaran. Harapan pada kegiatan ini untuk meningkatkan sikap, sifat dan perilaku sebagai wirausaha yang kritis dan peduli terhadap lingkungan sekitarnya serta meningkatkan kepemilikan asset produktif pengusaha UKM sasaran.

Luaran penelitian ini, untuk menghasilkan Model Pemberdayaan Pengusaha Kecil Mikro di KawasanPesisir Pantai Cemara Lembar Kabupaten Lombok Barat. Selanjutnya hasil penelitian ini akan dipublikasikan pada Jurnal Ilmiah Fakultas Ekonomi dan Bisnis Universitas Mataram.

Lokasi penelitian adalah Kawasan Pesisir Pantai Cemara Lembar Kabupaten Lombok Barat. Daerah ini terdapat potensi 
lokal yang belum optimal dikelola oleh pengusaha kecil/ mikro dan kondisi ekonominya tergolong miskin serta tidak memiliki kemampuan pengelolaan usaha.

Data primer yang dikumpulkan melalui survey lapangan di kawasan pesisir Pantai Cemara Lembar Kabupaten Lombok Barat untuk mengidentifikasi kondisi usaha dari pengusaha kecil mikro. Pengumpulan data primer ini, dibantu dengan kuisioner yang telah dipersiapkan sebelumnya. Sedangkan analisis data pada penelitian ini menggunakan analisisDeskriptif dan AHP untuk mengetahui produk perioritas (potensi lokal), sedangkan analisis Biaya dan Pendapatan untuk mengetahui peluang dan kelayakan usaha.

\section{HASIL DAN PEMBAHASAN}

\section{Kondisi Umum Desa Sekotong Tengah}

Kawasan pesisir Pantai Cemara secara fisik termasuk wilayah pesisir yang merupakan daerah yang potensial bagi pengembangan usaha dibidang perikanan. Namun karena pengetahuan dan tingkat kesadaran masyarakat yang relatif rendah merupakan faktor penyebab pemanfatan kawasan ini belum dikelola secara optimal. Ditinjau dari ketersediaan lahan yang potensial untuk pengembangan budidaya, lahan tambak yang terdapat di kawasan pesisir pantai Cemara merupakan hasil konversi mangrove.Pengembangan budidaya sesungguhnya dapat dimanfaatkan untuk pengembangan tambak udang maupun bandeng, sehingga dapat memberikan nilai ekonomi. Ketidakefisienan konversi lahan yang telah dilakukan, sementara konversi lahan tersebut dapat mengganggu keseimbangan lingkungan mengingat fungsi hutan mangrove sebagai perlindungan daerah setempat. Kondisi ini harus segera diatasi agar kerusakan lingkungan yang lebih parah dimasa yang akan datang dapat diantisipasi.

Kondisi di atas jika tidak segera dicarikan solusinya, maka kedepan keberadan ekosistem mangrove di kawasan pesisir dan laut Pantai Cemara Lembar akan mengalami kerusakan yang cukup berat dan membutuhkan biaya yang cukup besar untuk melakukan rehabilitasi. Dampak lain yang akan terjadi adalah hilangnya sumberdaya ikan yang menjadi sumber matapencaharian masyarakat, karena keberadaan ekosistem mangrove di daerah ini memiliki makna yang cukup strategis bagi pengembangan sumberdaya ikan, mengingatsalah satu fungsi ekologis dari ekosistem mangrove yang cukup penting adalah sebagai tempat ikan melakukan pemijahan atau bertelur dan sebagai sumber nutrien bagi kesuburan perairan. Selain fungsi di atas ekosistem mangrove juga dapat berperan untuk mencegah terjadinya abrasi pantai.

Kualitas sumberdaya manusia di kawasan pesisir Pantai Cemara Lembar, dilihat dari tingkat pendidikan tergolong rendah. $\mathrm{Hal}$ ini tercermin dari masih banyaknya jumlah penduduk yang berpendidikan Sekolah Dasar dan tidak/belum Tamat Sekolah Dasar. Berdasarkan Profil Dusun, bahwapenduduk yang putus sekolah dan belum tamat Sekolah Dasar (SD)44,84\%., dan penduduk berpendidikan Sekolah Dasar hampir sama yakni $43.92 \%$. Untuk penduduk yang memiliki pendidikan Sekolah Menengah Pertama (SLTA) dan Sekolah Menengah Atas (SLTA) masing-masing $8,85 \%$ dan $1,89 \%$. Selanjutnya penduduk yang tingkat pendidikan yang paling tinggi tergolong sangat sedikit hanya $0,5 \%$.

Tingkat kesehatan di kawasan pesisir Pantai Cemara Lembar masih tergolong rendah, tetapi sekarang sudah ada kemajuan bila dibandingkan dengan waktu-waktu yang lalu. Tingkat derajat kesehatan merupakan salah satu indikator tingkat kesejahteraan masyarakat. Antara kesehatan dengan kesejahteraa memiliki korelasi, semakin tinggi tingkat kesejahteraan masyarakat semakin tinggi derajat kesehatannya. Masyarakat yang sejahtera berarti kebutuhan primernya telah terpenuhi, termasuk aspek kesehatan. Kesehatan di kawasan pesisir Pantai Cemara Lembar diarahkan agar pelayanan kesehatan meningkat lebih luas,lebih merata dan lebih terjangkau sehingga dapat menghasilkan derajat kesehatan masyarakat yang lebih tinggi, pada akhirnya setiap orang bisa hidup lebih produktif secara sosial maupun secara ekonomis.

Ditinjau dari aspek sosial kependudukan dan tenaga kerja masih 
menampakkan kondisi yang kurang menguntungkan baik dari aspek kuantitas maupun kualitas. Kondisi sosial kependudukan dan tenaga kerja di kawasan pesisir Pantai Cemara Lembar Kabupaten Lombok Barat bila dicermati melalui beberapa indikator seperti kelompok umur penduduk, angka ketergantungan, tingkat pendidikan, angkatan kerja, pekerjaan utama dan tingkat pendidikan penduduk umur kerja masih memerlukan langkah-langkah operasional untuk dapat menggerakkan potensi penduduk secara optimal.

Karakteristik masyarakat pengusaha kecil/mikro dibidang perikanan yang merupakan responden sasaran penelitian meliputi :

a. Usia responden pengusaha UKM dibidang perikanan tergolong usia produktif yang akan dapat mempengaruhi tingkat produktivitasnya. Ini sesuai dengan struktur umur/usia pengusaha UKM di kawasan Pantai Cemara lembar, umurnya bervariasi dengan kisaran 24-66 tahun.

b. Tingkat pendidikan pengusaha UKM responden yang dominan adalah tingkat Sekolah Menengah Pertama (SMP) sekitar 51 persen, sedangkan tingkat pendidikan Sekolah Dasar (SD) sebanyak 28 persen dan Sekolah Menengah Atas (SMA) kurang lebih 21 persen.

Berdasarkan pengalaman, tidak bisa kita pungkiri bahwa tingkat pendidikan merupakan cerminan tingkat penguasaan seseorang terhadap suatu pengetahuan yang aplikasinya terlihat sebagai sikap wirausahanya. Tingkat pendidikan juga memiliki peranan yang sangat besar dalam proses penerapan teknologi dan inovasi baru.

c. Bidang usaha yang tekuni oleh masyarakat dibidang perikanan, setelah diinventarisir sebagian besar usaha pengolahan terasi udang, kemudian usaha kerupuk ikan dan budidaya tambak udang, bandeng, kepiting, usaha tambak garam serta usaha dagang ikan. Dari sekian usaha tersebut yang akan dianalisis kelayakan usaha dibidang perikanan adalah pengolahan terasi udang, budidaya tambak udang dan usaha dagang ikan.

d. Modal usaha yang digunakan oleh pengusaha UKM, hampir sebagian besar mengunakan modal sendiri, sedangkan modal pinjaman hanya sebagian kecil saja. Bagaimanapun modal usaha ini sangat dibutuhkan didalam pengembangan usahanya, oleh karena itu perlu dicarikan solusi untuk mendapatkannya, misalnya bantuan kredit lunak, dana bergulir dan lain sejenisnya.

e. Rata-rata per bulan hasil penjualan dari pengusaha/UKM bervariasi berkisar antara Rp 1.200.000,- sampai Rp 9.000.000,- Sedangkan secara rata-rata per bulan hasil penjualan dari 20 pengusaha UKM dibidang perikanan adalah sebesar Rp 3.900.000,-

Berikutnya, bila dari sisi tingkat keuntungan dapat diketahui bahwa ternyata rata-rata per bulan juga bervariasi dengan kisaran antara $\mathrm{Rp}$ 750.000,- sampai Rp 2.750.000,Sedangkan secara keseluruhan rata-rata per bulan per pengusaha UKM kurang lebih sebesar Rp 1.520.000,-

\section{Analisis Peluang dan Kelayakan Usaha di Kawasan Pesisir Pantai Cemara.}

Berdasarkan hasil observasi/survey di lapangan dan kajian komprehensif terhadap aspek ekonomi, kesesuaian sumberdaya alam dan lingkungan, serta aspek sosial dan aspek kelembagaan bahwa ketiga usaha dibidang perikanan di atas yang memungkinkan untuk dikembangkan di kawasan pesisir Pantai Cemara Lembar.Dalam analisis peluang dan kelayakan usaha ini, dilakukan dengan kajian disajikan hasil analisis biaya dan pendapatan usaha terasi udang, usaha dagang ikan dan usaha tambak budidaya udang yang dilakukan secara tradisional.

a. Usaha Terasi Udang

Hasil tangkapan maupun hasil budidaya udang di kawasan pesisir Pantai Cemara Lembar tergolong cukup tinggi. Masalahnya dari produk tangkapan tersebut adalah pemanfaataan yang masih terbatas, diantaranya dikonsumsi segar, diasinkan dan diasap. Padahal dengan sentuhan teknologi pasca panen yang sederhana, hasil tangkapan maupun budidaya tersebut dapat diolah menjadi produk terasi udang yang memberikan nilai tambah pada produk tersebut yang pada 
gilirannya dapat meningkatkan kesejahteraan petani ikan maupun masyarakat di sekitar lokasi.

Untuk kajian atau analisis biaya dan pendapatan usaha terasi udang sama dengan yang lain diusahakan secara tradisional, menunjukkan bahwa biaya untuk usaha terasi udang sebesar $\mathrm{Rp}$ 150.000 yang berlangsung selama satu bulan. Dari jumlah biaya tersebut, dapat memperoleh pendapatan bersih $\mathrm{Rp}$ 1.100.000 dalam satu bulan.

Dengan nilai Gross Margin (GM) atau pendapatan bersih sebesar tersebut diatas usaha terasi udang secara ekonomi memang menguntungkan, namun tidak efisien jika dilihat dari penggunaan biaya operasional usahanya karena nilai Gross Ratio kurang dari $20 \%$ yaitu sebesar 0,12 atau $12 \%$. Berikutnya pada tingkat profitabilitasnya, juga menguntungkan karena nilai Contribution Margin (CM) mampu memberikan $88 \%$ (indikator diatas $60 \%)$, artinya pengelolaan biaya total dalam proses produksinya tergolong efisien. Usaha terasi udang memang layak dikembangkan di desa Sekotong Tengah, dapat dibuktikan dari nilai Gross B/C Ratio sebesar 8,33 (kriteria diatas 1,0).

b. Usaha Budidaya/Tambak Udang Hasil budidaya tambak udang di kawasan pesisir Pantai Cemara Lembar tergolong cukup, masalahnya adalah cara penanganan yang masih sederhana/tradisional. Sesungguhnya dapat memberikan keuntungan dan manfaat yang cukup besar, bila usaha budidaya udang ini diolah dengan sentuhan teknologi yang sederhana sekalipun.

Untuk kajian atau analisis biaya dan pendapatan usaha budidaya tambak udang sama dengan yang lain diusahakan secara tradisional, menunjukkan bahwa biaya untuk usaha ini sebesar Rp 5.000.000,yang berlangsung selama tiga bulan. Dari jumlah biaya tersebut, dapat memperoleh pendapatan bersih $\mathrm{Rp} 2.600 .000$ dalam empat bulan.

Dengan nilai Gross Margin (GM) atau pendapatan bersih sebesar tersebut diatas usaha budidaya udang secara ekonomi memang menguntungkan, dan juga efisien jika dilihat dari penggunaan biaya operasional usahanya karena nilai Gross Ratio lebih dari 20\%. Namun dilihat pada tingkat profitabilitasnya, tidak menguntungkan karena nilai Contribution Margin (CM) hanya mampu memberikan 34,21\% (indikator dibawah $60 \%$ ), artinya pengelolaan biaya total dalam proses produksinya tergolong tidak efisien. Usaha budidaya udang memang layak dikembangkan di kawasan pesisir Pantai Cemara Lembar, dapat dibuktikan dari nilai Gross B/C Ratio sebesar 1,52 (kriteria diatas $1,0)$.

c. Usaha Dagang Ikan

Terakhir yang dianalisis biaya dan pendapatan dalam penelitian ini adalah usaha dagang ikan. Kondisi dagang ikan tidak beda dengan kondisi usaha dagang (kios) maupun usaha dagang pada umumnya, bahwa setiap pedagang mempunyai tujuan yang ingin dicapai adalah untuk mendapatkan laba/keuntungan dan kelangsungan kontinuitas usaha dagang itu sendiri.

Berdasarkan perhitungan analisi biaya dan pendapatan pada tabel diatas, bahwa biaya yang dikeluarkan pengusaha UKM dagang ikan dalam operasional satu bulan $\mathrm{Rp} \quad 1.700 .000$ dengan pendapatan bersihnya Rp 850.000. Sama halnya dengan usaha dagang lainnya, kajian atau analisis pada usaha dagang ikan dengan manajemen sederhana.

Dengan pendapatan bersih sebesar tersebut termasuk menguntungkan secara ekonomi,-. Demikian juga dengan tingkat efisiensi, usaha ini menguntungkan dengan nilai Gross Ratio (GR) sebesar $60,71 \%$ (indikator diatas 20\%), artinya pengelolaan biaya operasional dalam proses produksinya tergolong efisien. Dari sisi kelayakan usaha dagang ikan sedikit layak dikembangkan di kawasan pesisir Pantai Cemara Lembar karena nilai Gross B/C Ratio sedikit diatas 1,0. Tetapi dalam penggunaan biaya keseluruhan tidak efisien dikarenakan nilai Contribution Margin $(C M)=30,36 \%$ (indikator kurang dari $60 \%$, artinya biaya total yang dikeluarkan pengusaha dagang ikan sekali proses produksi (satu bulan) kurang $60 \%$ 
dari nilai produksi yang diperoleh.

\section{Model Pemberdayaan UKM}

Besarnya potensi sektor perikanan, perikanan dan perkebunan baik dari ketersediaan lahan maupun kesiapan masyarakat dalam mengelola komoditi di kawasan pesisir Pantai Cemara Lembar merupakan hal yang perlu mendapat perhatian dari berbagai pihak untuk memanfaatkan potensi yang ada melalui upaya pemberdayaan UKM dengan menangani potensi lokal tersebut secara baik dan terencana. Melalui pemberdayaan UKM, ekonomi masyarakat diharapkan bisa berkembang/meningkat dan pada akhirnya dapat mengentaskan kemiskinan yang ada di kawasan pesisir Pantai Cemara.

Berdasarkan hasil diskusi terbatas melalui Fokus Group Discussion (FGD) yang dilaksanakan Tim Peneliti dengan dihadiri peserta dari pelaku usaha (UKM), tokoh masyarakat dan pemuda terdapat beberapa tanggapan dan masukan yang dapat dirumuskan sebagai berikut : a. UKM penting diperlukan sebagai peran ikut menggerakan ekonomi masyarakat dan pengembangan ekonomi masyarakat di kawasan pesisir Pantai Cemara Lembar, oleh karena itu perlu membentuk Kelompok UKM.

b. Pemberdayaan UKM memerlukan bantuan pemerintah dan stakeholderdalam hal bantuan modal usaha dan pembinaan/pengembangan SDM (ketrampilan), tanpa ada komitmen ini upaya yang akan dilaksanakan pasti akan gagal.

c. Perlu adanya jaringan/kemitraan usaha yang dapat memperlancar kegiatan/operasional usaha dalam rangka pemberdayaan UKM.

Dari hasil tanggapan dan masukan pada Fokus Group Discussion (FGD), dapat dibuatkan Model Pemberdayaan UKM melalui alur bagan/gambar sebagai berikut :

Gambar 1. Model Pemberdayaan UKM

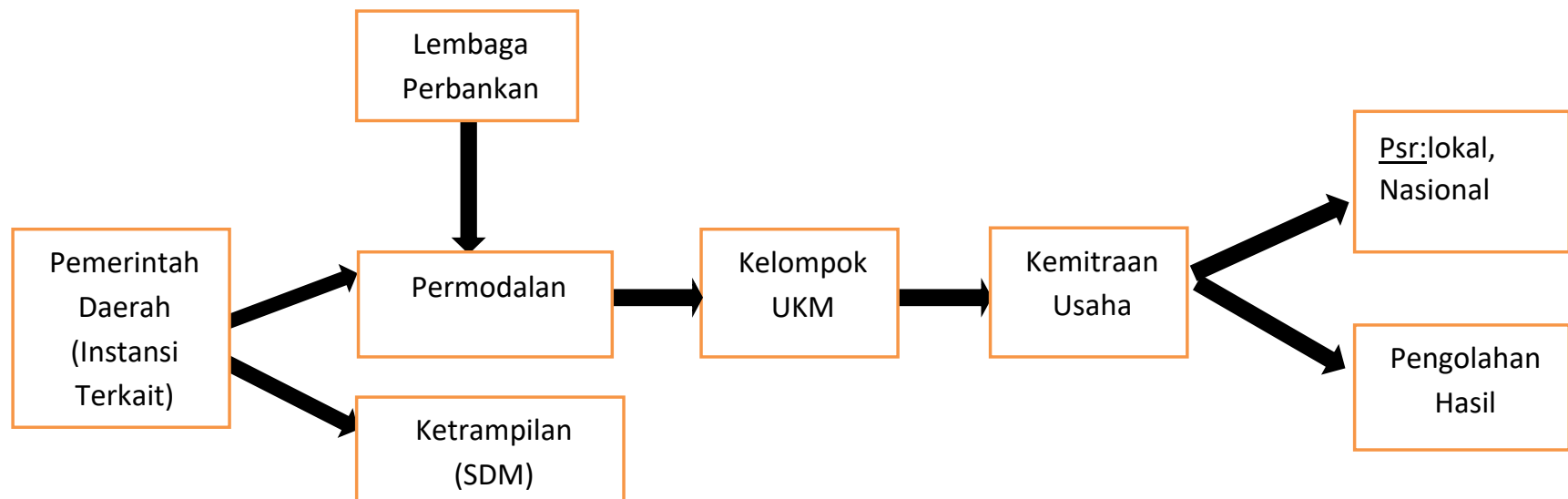

Berdasarkan bagan/gambar Model Pemberdayaan UKM pada tampilan di atas dapat diuraikan sebagai berikut :

a. Pemerintah daerah dalam hal ini instansi terkait seperti Dinas Koperasi \& UKM dan Dinas Perindustrian \& Perdagangan diharapkan memberikan bantuan modal usaha

b. bagi UKM selain juga dari Lembaga Perbankan. Dari instansi terkait ini pula diharapkan dapat memberikan pelatihan atau sejenisnya untuk meningkatkan c. ketrampilan UKM (SDM) agar dapat mengolah usahanya dengan profesional.

d. Pemberdayaan UKM dalam mengelola komoditi potensial/unggulan perlu dibentuk Kelompok Usaha (UKM) yang merupakan wadah kelembagaan yang berperan dalam menjaga keseimbangan posisi tawar anggota UKM yang tentunya diharapkan memberikan manfaat/keuntungan yang optimal.

e. Perlu adanya kemitraan usaha yang berhubungan dengan kelompok usaha, dimana mitra usaha lain dapat melakukan pengolahan hasil produk UKM maupun 
memasarkannya di pasar lokal maupun nasional.

\section{KESIMPULAN DAN SARAN}

\section{Kesimpulan}

Dari hasil penelitian yang diuraikan diatas dapat disimpulkan sebagai berikut :

1. Pada kawasan pesisir PantaiCemara Lembar memiliki potensi lokal dibidang perikanan yang dapat dikembangkan masyarakat (UKM), namun belum dikelola secara optimal. Usaha pengolahan terasi udang, dagang ikan dan budidaya tambak udang ditinjau dari sisi ekonomi memberikan keuntungan. Demikian juga dilihat dari sudut kelayakan, dengan nilai B/C Ratio masing-masing 9,60 dan 1,52 serta 1,44

2. Potensi lokal yang dapat dikembangkan dari hasil survey dengan melalui proses analisis Deskriptif, AHP dan kemudian dibahas dalam forum FGD maka disepakati adalah budidaya udang, usaha terasi udang dan usaha dagang ikan.

3. Bedasarkan hasil FGD, maka dibentuk
Model Pemberdayaan UKM Berbasis Potensi Lokal Dalam Rangka Pengentasan Kemiskinan Di Kawasan Pesisir Pantai Cemara Lembar, dimana :

4. Adanya peran Pemerintah dalam memberikan bantuan modal selain dari lembaga Perbankan dan bantuan ketrampilan (SDM)

5. UKM membentuk Kelompok (lembaga) sebagai wadah dalam pengembangan usaha

6. Perlu adanya Mitra Usaha dalam membantu memasarkan dan pengolahan hasil usaha.

\section{Saran}

1. Untuk penerapan model pemberdayaan UKM ini, sebaiknya pihak-pihak terkait perlu menindaklanjuti terutama instansi pemerintah, stokhalder maupun pengusaha UKM itu sendiri.

2. Pengusaha UKM perlu pembinaan dan pendampingan yang dilakukan secara teratur, tertib dan disiplin serta kontinyuitas oleh semua pihak terutama dari pemerintah

\section{DAFTAR PUSTAKA}

Anonim, 2006, Laporan Tahunan, Badan Pusat Statistik RI, JakartaAchmad E, dkk, 2003, Pengelolaan dan Perencanaan Terpadu Sumberdaya Pesisir Kecamatan Sekotong Lombok Barat, NTB. Small-Scale Natural Resurces Management Schemes MCRMP

Achmad E, Masrun, Hilyana S, 2011, Pengentasan Kemiskinan Melalui Pembinaan Sikap Mental Wirausaha Pada Masyarakat Pesisir Desa Kebun Talu Labuhan Tereng Kecamatan Lembar Lombok Barat

Amirawulandari, 2007, Peranan UKM Terhadap Pertumbuhan Perekonomian Di Indonesia

Hafsah, M.J, 2004, Upaya Pengembangan UKM, Infokop, No. 25 Tahun XX

Jufri A, dkk, 2015, Pembinaan Wirausaha UKM Dalam Rangka Penguatan Ekonomi Masyarakat Di Kawasan Pesisir Desa Sekotong Tengah Kabupaten Lombok Barat

Nikujuluw, V, 2011, Penyusunan Rencana Pengelolaan Kawasan Pesisir dan Laut

Prawirokusumo, 2000, UKM Memperkuat Ekonomi Nasional, Infokop, Tahun, XVI

Situmorang, J, 2008, Strategi UMKM Dalam Menghadapi Iklim Usaha Yang Tidak Kondusif, Infokop, Vol. 16

Sukandarrumidi, 2009, Berkembang Sebagai Entrepreneur, Yayasan Pustaka Nusantara, Yogyakarta

Tambunan, T, 2002, UKM Di Indonesia : Beberapa Isu Penting, Salemba, Jakarta 
681 Masrun, Akhmad Jufri, Titi Tuniarti/Model Pemberdayaan VKM....

2005, Promoting Small and Medium Enterprises With a Clustering Approach : A. Policy Experince From Indonesian, Journal Of Small Business Management, Vol. 43, No.2

Winarni, E.S, 2006, Strategi Pengembangan Usaha Kecil Melalui Peningkatan Aksesibilitas Kredit Perbankan, Infokop, No.29, Tahun, XXII

World Bank, 2001, World Develompment Report 2000/2001, Attacking Poverty

Yao, Guevera Assamoi, 2007, Fiscal Decentralization and Poverty Reduction Outcomes, Theory and Evidence, George State University. 